\title{
Carcinoma Originating from the Ectopic Mammary Gland of the Axilla
}

\author{
H.L.A. Hamid ${ }^{a}$ M.M. Farghaly ${ }^{a}$ H.I. Baker ${ }^{b}$ M.S. Al-Manee ${ }^{a}$ \\ aDepartment of Surgery Al-Adan Hospital, and ' Kuwait Cancer Control Centre, Kuwait
}

\section{Key Words}

Ectopic breast · Axilla $\cdot$ Carcinoma $\cdot$ Kuwait

\begin{abstract}
Carcinoma originating from ectopic breast tissue is a rare condition comprising only $0.3 \%$ of all breast cancers. The case presented here is the first of its kind to be reported in Kuwait. A review of the literature is provided, and a rationale for the treatment of this condition.

Copyright $\odot 2001$ S. Karger AG, Basel
\end{abstract}

\section{Introduction}

Ectopic breast tissue may occur anywhere along the embryonic milk line. Carcinoma of the axillary breast is a rare finding, accounting for approximately $0.3 \%$ of all breast cancers. A search of the literature showed that, to date, a total of 95 cases of carcinoma of ectopic

\begin{tabular}{ll}
\hline KARGER & ( 1998 S. Karger AG, Basel \\
1011-7571/00/0093-0194\$17.50/0 \\
$\begin{array}{l}\text { Fax +4161306 12 34 } \\
\begin{array}{l}\text { E-Mail karger@karger.ch } \\
\text { www.karger.com }\end{array}\end{array}$ & $\begin{array}{l}\text { Accessible online at: } \\
\text { www.karger.com/journals/mpp }\end{array}$
\end{tabular}

breast tissue have been reported worldwide, 69 of which occurred in the axilla [1-6].

The correct preoperative diagnosis is rarely made for this condition. We report a case of carcinoma originating from ectopic breast tissue of the axilla, and review the available literature. Wide local excision and axillary lymph node dissection are necessary [7]. Adjuvant chemotherapy and irradiation, together with endocrine therapy, improve the outcome [8, 9].

\section{Case Report}

A 49-year-old woman presented with a slowly growing painful lesion in the left axilla, which had been slowly growing for the past 2 years. Both the size of the swelling and the pain increased during her regular menstrual cycles. She was not on contraceptive pills or hormonal treatment. The lesion was $2.5 \times 1.5 \mathrm{~cm}$ in diameter, hard in consistency, brown in colour with central punctum and attached to the overlying skin. Bilateral mammography and breast ultrasound ruled out any associated lesion. Fine-needle aspiration cytol-

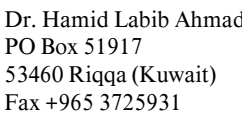


Fig. 1. Malignant lobular carcinoma cells in 'indian file pattern' surrounding skin adenexal glands of axilla. HE. $\times 400$.

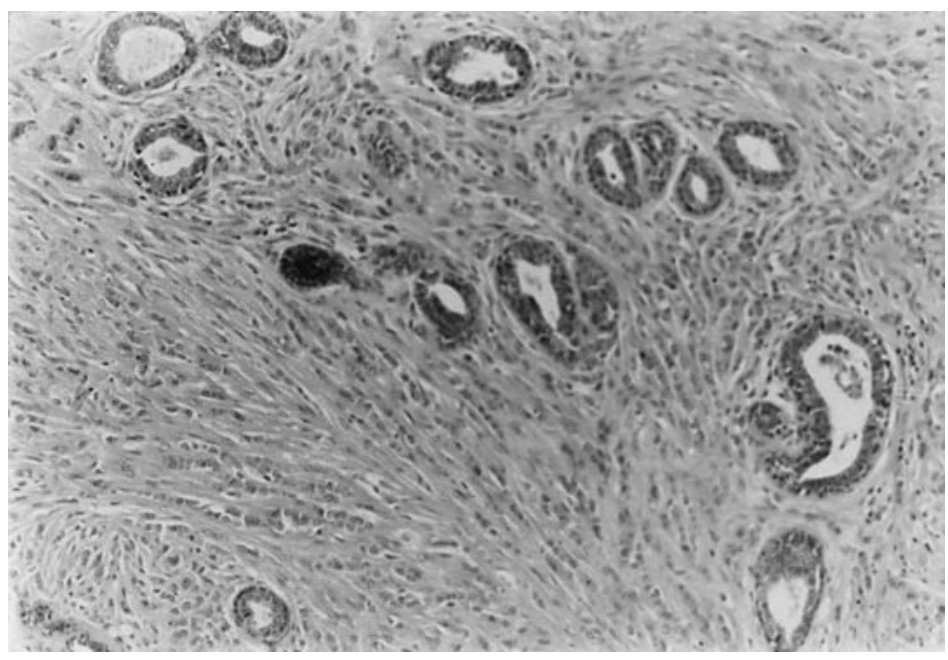

Fig. 2. Cells of invasive lobular carcinoma showing intracytoplasmic lumina. $\mathrm{HE} \times 800$.

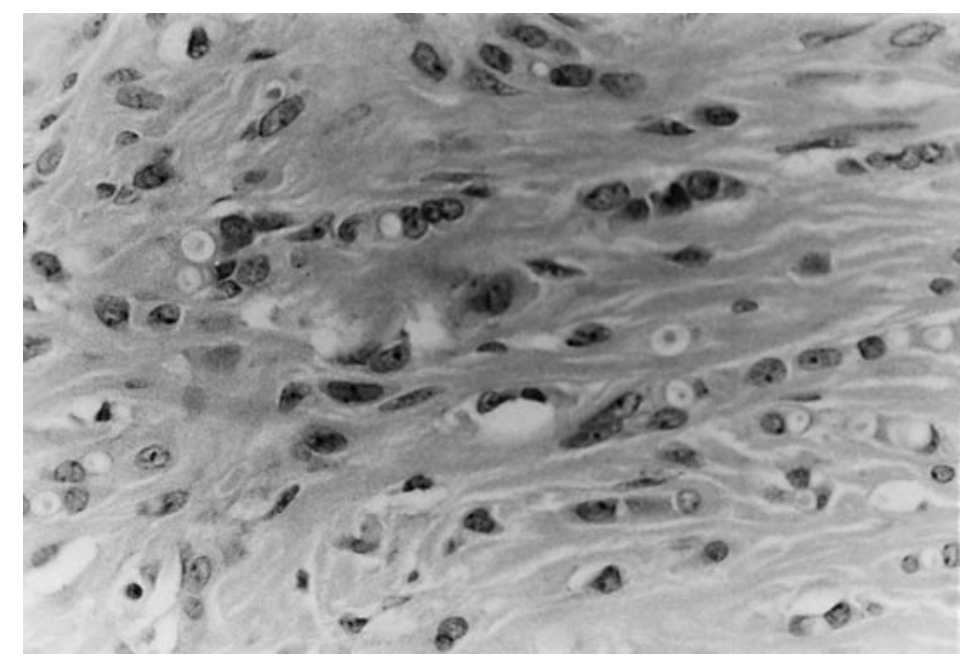

ogy was benign. Under general anaesthesia, the patient underwent wide local excision together with axillary dissection. Frozen section was negative for malignancy. However, paraffin sections revealed invasive lobular carcinoma arising from ectopic breast tissue in the axilla (fig. 1,2). The tumour diffusely infiltrated the densely fibrotic dermis and the subcutaneous tissue. The tumor did not invade the epidermis. Oestrogen receptors were positive, as determined by immunohistochemical examination. Resection lines were free of tumour. One out of 14 lymph nodes showed a tiny tumour deposit in its perinodal fat. Chest X-ray, liver ultrasound examination and bone scan were normal.
The patient received 6 cycles of adjuvant chemotherapy: cyclophosphamid, methotrexate, 5-fluorouracil (CMF) for a total of 6 courses, together with tamoxifen $20 \mathrm{mg}$ daily for 5 years.

Radiation therapy for the internal mammary and supraclavicular lymph nodes was given upon completion of the CMF course. Regular follow-up up to 36 months revealed no clinical or radiological evidence of local recurrence or distant metastasis. 


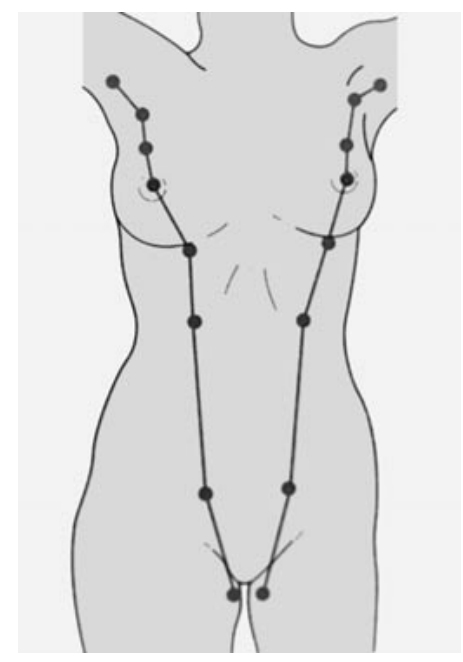

Fig. 3. Diagram of the milk line demonstrating sites of supernumerary nipples and breast tissue.

\section{Embryological Characteristics}

Breasts are skin appendages arising from ectodermally derived mammary lines in the embryo. This line extends from the forelimb to the region of the hind limb in the 7-mm embryo. Development of the breasts proceeds identically in both sexes during foetal life (fig. 3). Most of the mammary line disappears soon after its formation, but a small portion in the thoracic region persists and thickens to form the mammary primordium. The ectoderm of the primordium penetrates to the underlying mesenchyme and gives rise to $15-$ 25 epithelial strips that, by the end of prenatal life, canalise and form the lactiferous ducts and the alveoli of the mammary gland. The primitive lactiferous duct system begins peripherally and proceeds towards the eventual nipple/areola complex. They begin by opening into an epithelial pit, which at term or later gives rise to the nipple as a consequence of proliferation of surrounding mesoderm.
Usually, the mammary line persists only in the thoracic region in the human, but occasionally residual fragments give rise to accessory mammary tissue. Accessory breast tissue may take several forms. It has been classified in the following manner: (1) complete breast with nipple, areola and glandular tissue; (2) supernumerary breast without areola, but with nipple and glandular tissue; (3) supernumerary breast without nipple, but with areola and glandular tissue; (4) aberrant glandular tissue without nipple and areola; (5) pseudomamma with nipple and areola, but without glandular tissue - the breast is replaced by fat; (6) polythelia - presence of a nipple only; (7) Polythelia areolaris - presence of an areola only, or (8) polythelia pilosa - presence of a patch of hair only.

While aberrant breast tissue usually develops somewhere along the embryonic mammary line, in rare instances it has appeared in other unusual sites such as the shoulder, buttocks or face. Supernumerary nipples can be identified at birth, whereas ectopic breast tissue becomes noticeable only after hormonal stimulation, usually during puberty, pregnancy or lactation.

\section{Discussion}

The mammary line persists only in the thoracic region in humans, but occasionally residual fragments give rise to accessory mammary tissue. Polymastia has been found in approximately $2-6 \%$ of women $[10,11]$, whereas the majority of women with polymastia have only 1 additional breast, 2 or more are not uncommon, and up to 10 additional pairs of breast have been reported [11]. Supernumerary breast tissue and nipples are often dismissed as cosmetic curiosities. These structures have the potential for pathologic degeneration and may be associated with significant 
congenital abnormalities of the urinary and cardiovascular systems. Urbani and Betti [12] found a significantly higher frequency of kidney and urinary tract malformations in cases that had accessory mammary tissue. The affected patients compared to the controls were $7.53 \%$ versus. $0.68 \%$, respectively [13]. A supernumerary nipple is also regarded as a cutaneous paraneoplastic marker because of its significant association with urogenital malignancy [13-16]. The incidence of carcinoma in an ectopic breast is rare $[1,8]$. It is difficult to predict the prognosis since some authors suggested that the outlook might be worse than carcinoma occurring in pectoral breasts because of the earlier involvement of the draining lymph nodes [9]. Other reports showed long-term survival in node-negative patients $[8,17,18]$. Evans and Guyton [1] quote the work by Razemon and Rizard, who in 1927 collected a series of 17 cases of which 13 were treated by breast preservation and axillary dissection and 4 by radical mastectomy. Ten of them recurred within 2 years of surgery, and 3 survived for less than 2 years. They concluded that additional, radical or modified radical mastectomy offered no advantage in outcome over axillary mastectomy and regional node dissection $[9,17,18]$.

\section{Conclusion}

Pathologic changes are liable to develop in an axillary breast. This creates a diagnostic challenge. Awareness and high index of suspicion of extramammary swellings along the milk line that correlates with menstruation or pregnancy is strongly emphasized. Early wide excision of such lesions may improve survival.

Treatment policy should be similar to that advocated for breast cancer in general. Longterm follow-up is essential.

\section{References}

1 Evans DM, Guyton DP: Carcinoma of the axillary breast. J Surg Oncol 1995;59:190-195.

2 Yerra L, Karnad AB, Primary breast cancer in aberrant breast tissue in the axilla. South Med J 1997;90: 661-662.

3 Drozdz M, Pardela M: A case of ectopic breast tissue located in the axilla. Ginekol Pol 1997;68:636640.

4 Nakao A, Saito S, Inoue F, Notohara $\mathrm{K}$, Tanaka N: Ectopic breast cancer: A case report and review of the Japanese literature. Anticancer Res 1998;18:3737-3740.

5 Routiot T, Marchal C, Grosh WW, Rice LW, Andersen WA: Breast carcinoma located in ectopic breast tissue: A case report and review of the literature. Oncol Rep 1998;5:413417.

Carcinoma Originating from the

Ectopic Mammary Gland of the Axilla
6 Irvin WP, Cathro HP: Primary breast carcinoma of the vulva: A case report and literary review. Gynecol Oncol 1999;73:155-159.

7 Copland MM, Geschickter CF: Symposium on diagnosis and treatment of premalignant conditions. Surg Clin North Am 1950;30:17171741.

8 Smith GMR, Greening WP: Carcinoma of aberrant breast tissue. Br J Surg 1972;59:89-90.

9 Routiot T, Marchal C: Breast carcinoma located in ectopic tissue: A case report and review of the literature. Oncol Rep 1998;5:413-417.

10 Langman J: Medical Embryology. Baltimore, Williams \& Wilkins, 1969, pp 367-368.

11 DeCholnoky T: Supernumerary breast. Arch Surg 1939;39:926-941.

12 Urbani CE, Betti R: Accessory mammary tissue associated with congenital and hereditary nephrourinary malformations. Int J Dermatol 1996;35:349-352.
13 Pellegrini JR, Wagner RF: Polythelia and associated conditions. Am Fam Physician 1983;28:129-132.

14 Velanovich V: Ectopic breast tissue, supernumerary breasts, and supernumerary nipples. South Med J 1995;88:903-906.

15 Urbani CE, Betti R: Aberrant mammary tissue and nephrourinary malignancy. Cancer Genet Cytogenet 1996;87:88-89.

16 Goedert JJ, McKeen EA: Polymastia and renal adenocarcinoma. Ann Intern Med 1981;95:182-184.

17 Youn SN: A case report of infiltrating ductal carcinoma originating from aberrant breast tissue. J Dermatol 1994;21:960-964.

18 Yerra L, Karnad AB: Primary breast cancer in aberrant tissue in the axilla. South Med J 1997;90:661-662. 